\begin{abstract}
Iranica
Abstracta Iranica Revue bibliographique pour le domaine irano-aryen

Volume 34-35-36 | 2017

Comptes rendus des publications de 2011-2013
\end{abstract}

\title{
Susan Ackerman. The Mother of Eshmunazor, Priest of Astarte: A Study of her Cultic Role
}

\section{Astrid Nunn}

\section{OpenEdition}

\section{Édition électronique}

URL : http://journals.openedition.org/abstractairanica/41209

DOI : 10.4000/abstractairanica.41209

ISSN : 1961-960X

Éditeur :

CNRS (UMR 7528 Mondes iraniens et indiens), Éditions de l'IFRI

\section{Référence électronique}

Astrid Nunn, «Susan Ackerman. The Mother of Eshmunazor, Priest of Astarte: A Study of her Cultic Role», Abstracta Iranica [En ligne], Volume 34-35-36 | 2017, document 94, mis en ligne le 15 juillet 2016, consulté le 27 septembre 2020. URL : http://journals.openedition.org/abstractairanica/41209; DOI : https://doi.org/10.4000/abstractairanica.41209

Ce document a été généré automatiquement le 27 septembre 2020.

Tous droits réservés 


\title{
Susan Ackerman. The Mother of Eshmunazor, Priest of Astarte: A Study of her Cultic Role
}

\author{
Astrid Nunn
}

\section{RÉFÉRENCE}

Susan Ackerman. «The Mother of Eshmunazor, Priest of Astarte: A Study of her Cultic Role ». Die Welt des Orients, 43/2, 2013, p. 158-178.

1 L'A. traite le rôle religieux de la mère du roi sidonien Echmunazar, phénicienne et prêtresse d'Astarté. La riche documentation en Phénicie atteste la participation importante de prêtresses au culte d'Astarté même si, semble-t-il, cette participation était réservée aux femmes nées ou mariées dans un milieu de prêtres et sans droit au sacrifice. Bien que limitée, cette activité était contraire aux habitudes du monde syrocananéen, où les femmes ne participaient pas au culte.

\section{AUTEURS}

\section{ASTRID NUNN}

Université de Munich 